\title{
Voorwoord bij het themanummer gemetastaseerd prostaatcarcinoom
}

\author{
Liselotte M. S. Boevé1,2 · George van Andel ${ }^{1}$
}

Published online: 11 September 2019

(c) The Author(s) 2019

De ontwikkelingen rond de diagnostiek en behandeling van patiënten met een gevorderd prostaatcarcinoom zijn de laatste jaren aan verandering onderhevig en volgen elkaar in rap tempo op. Voor de praktisch ingestelde specialist zijn ze nauwelijks bij te houden en is er behoefte aan enig overzicht. Dat bieden we met dit themanummer rond het gemetastaseerd prostaatcarcinoom. Om te beginnen met de diagnostiek.

Daniela Oprea Leger en Emile Comans bespreken de waarde - voor zover bekend - van enkele traditionele en nieuwe beeldvormende technieken bij de diagnostiek van prostaatcarcinoom en adresseren het grote klinische dilemma van het toenemende gebruik van nieuwe beeldvormende technieken [1]. Met beeldvorming worden meer en eerder metastasen gedetecteerd, terwijl in studies waarop actuele therapeutische strategieën zijn gebaseerd, de traditionele beeldvormende technieken zijn gebruikt. Wat te doen als bij hedendaagse beeldvorming dan sprake blijkt van gemetastaseerde ziekte?

De Nederlandse HORRAD-studie is mondiaal de eerste prospectief uitgevoerde en gepubliceerde studie naar de waarde van lokale behandeling van de prostaat bij patiënten met een primair ossaal gemetastaseerd prostaatcarcinoom. Daar mogen we als Nederlandse urologen best trots op zijn. In een bondig overzicht onderbouwen Liselotte Boevé en collega's de nieuwe aanbeveling (EAU guidelines on prostate cancer) om patiënten met een primair gemetastaseerd prostaatcarcinoom en een lage metastaselast, behalve de standaard hormonale therapie, ook radicaal extern radiotherapeutisch te behandelen op de prostaat [2].

Gisèle Leyten en collega's beschrijven in een zeer fraai overzichtsartikel dat voor patiënten met een primair gemetastaseerd prostaatcarcinoom en een hoge metastaselast de therapie van eerste keuze bestaat uit de standaard hormo-

\footnotetext{
drs. Liselotte M. S. Boevé

1.boeve@olvg.nl

afdeling Urologie, OLVG, Amsterdam, Nederland

2 afdeling Urologie, Amsterdam Universitair Medische Centra, Locatie VUmc, Amsterdam, Nederland
}

nale therapie, in combinatie met docetaxel/prednison [3]. Daarnaast hebben zij alle behandelingsmogelijkheden bij patiënten met een hormoongevoelig en castratieresistent gemetastaseerd prostaatcarcinoom op een rijtje gezet. Verder worden in hun artikel toekomstige ontwikkelingen besproken en wordt aandacht besteed aan de directe behandeling van oligometastasen door middel van externe radiotherapie.

Binnen de oncologie zijn de laatste jaren grote vorderingen gemaakt met de doelgerichte en immuuntherapieën, al dan niet gebaseerd op predictieve biomarkers. Deze vorderingen betreffen met name de behandeling van het melanoom en het long- en niercelcarcinoom. In een niet zonder meer eenvoudig, maar wel zeer lezenswaardig en informatief Engelstalige artikel, beschrijven Minke Smits en collega's de actuele status van deze therapieën bij patiënten met een gemetastaseerd prostaatcarcinoom [4]. Het betreft een overzicht van predictieve biomarkers, zoals mismatch repairdeficiëntie en DNA-repairdeficiëntie, en veelbelovende nieuwe therapieën, zoals PSMA-ligandtherapie, behandeling met PARP-remmers en immunotherapie. Deze therapieën zullen naar de inschatting van de auteurs zowel als monotherapie, als in combinatieschema's hoogstwaarschijnlijk de behandeling van het prostaatcarcinoom in de komende tien jaar veranderen. De steeds beter geïnformeerde patiënt zal vaker vragen naar de mogelijkheden van 'immuuntherapie', en dus is voor een adequaat antwoord kennis nemen van dit artikel onontbeerlijk. Tevens vindt $\mathrm{u}$ in dit artikel een overzichtstabel met alle lopende onderzoeken. Indien patiënten gemotiveerd zijn, kunnen zij verwezen worden om te participeren in een onderzoek, teneinde antwoorden te vinden op de klinische vragen die op dit moment spelen.

Tot slot beschrijven Ronald ter Haar en collega's in een uitgebreid overzichtsartikel het klinisch beloop bij patiënten met een gemetastaseerd prostaatcarcinoom [5]. De behandeling van het gevorderde prostaatcarcinoom betreft niet alleen palliatieve therapieën die het leven verlengen, maar met name ook behandeling van de problemen waarmee patiënten worden geconfronteerd ten gevolge van de ziekteprogressie. Omdat er een trend is dat urologen langer zelf patiënten met een gemetastaseerd prostaatcarcinoom 
behandelen, is kennis van de aard van deze problemen, de behandeling daarvan en de noodzakelijke organisatie van deze zorg, noodzakelijk. Dit artikel ondersteunt daarbij.

Wij hopen dat u na het lezen van dit themanummer weer helemaal bij bent!

\section{Liselotte Boevé}

\section{George van Andel}

Open Access This article is distributed under the terms of the Creative Commons Attribution 4.0 International License (http:// creativecommons.org/licenses/by/4.0/), which permits unrestricted use, distribution, and reproduction in any medium, provided you give appropriate credit to the original author(s) and the source, provide a link to the Creative Commons license, and indicate if changes were made.

\section{Literatuur}

1. Oprea-Lager DE, Comans EFI. Nieuwe beeldvormende technieken bij de diagnostiek van het prostaatcarcinoom. Tijdschr Urol. 2019;6. In druk.

2. Boevé LMS, Hulshof MCCM, Vis AN, Vries P de, Moorselaar RJA van, Witjes WPJ, et al. Lokale behandeling bij het primair gemetastaseerd prostaatcarcinoom. Tijdschr Urol. 2019;6. In druk.

3. Leyten GHJM, Oort IM van, Bergman AM. Op metastasen gerichte behandeling van prostaatcarcinoom. Tijdschr Urol. 2019;6. In druk.

4. Smits M, Gerritsen W, Mehra N. Future therapeutic strategies for metastatic prostate cancer. Tijdschr Urol. 2019;6. In druk.

5. Haar RW ter, Boevé LMS, Hillenius J, Andel G van. Het klinisch beloop bij patiënten met een gemetastaseerd prostaatcarcinoom. Tijdschr Urol. 2019;6. In druk.

drs. Liselotte M.S. Boevé uroloog

dr. George van Andel uroloog 